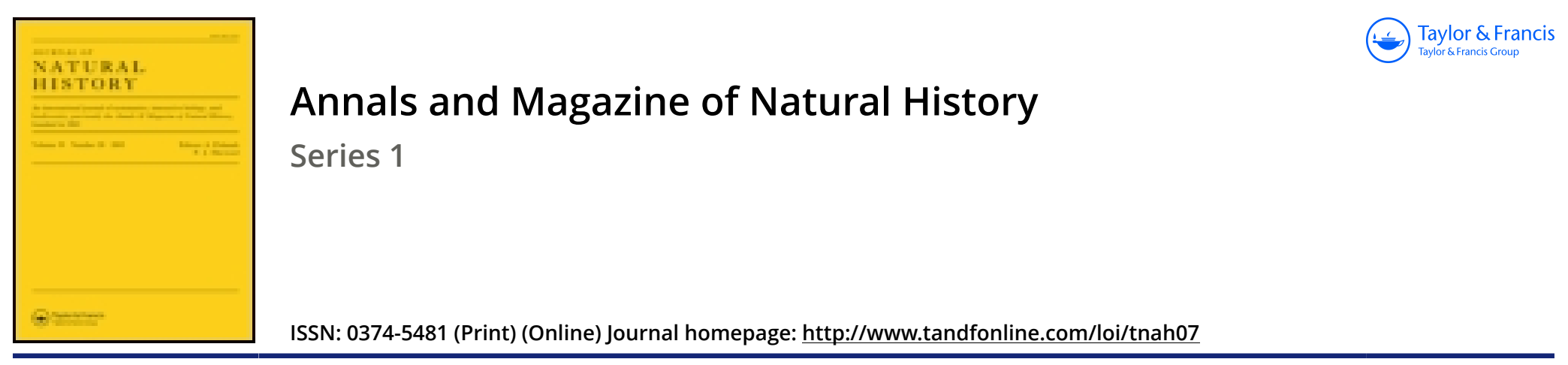

\title{
XVIII.-On the Laurus Cassia of Linnæus, and the plants producing the Cassia Bark of commerce
}

\section{Robert Wight M.D.}

To cite this article: Robert Wight M.D. (1839) XVIII.-On the Laurus Cassia of Linnæus, and the plants producing the Cassia Bark of commerce , Annals and Magazine of Natural History, 4:23, 179-185, DOI: $10.1080 / 00222933909512489$

To link to this article: http://dx.doi.org/10.1080/00222933909512489

$$
\text { 电 Published online: } 15 \text { Mar } 2010 .
$$

Submit your article to this journal $\sqsubset \pi$

Q View related articles $₫$ 
and died, and in lassoing one to fill the place of the latter, one of its legs was broken; so that three beasts were lost.

On reaching Ponto Morgues, 21 miles from Buenos Ayres, I took a horse and left the Tropa, which did not get to town till 5 days after, so bad are the roads close to the great metropolis of the Argentine Republic. I made my way home that very night that $I$ left the carts, 7 months after setting out, and so much was I disfigured with the effects of weather and sun, to say nothing of dirty and tattered garments, that several of my old acquaintances did not know me.

Thus I have given a detail of my pleasure trip across the vast plains of Buenos Ayres, a journey during which I may say that I have travelled on my own feet nearly 2000 miles, viz. from the Rio Segero on the N.E. to the foot of the Cordillera on the N.W., and seen, said, and done many things, with which it would be superfluous and impertinent to trouble you.

XVIII.-On the Laurus Cassia of Linnceus, and the Plants producing the Cassia Bark of Commerce. By Ronent Wight, M.D.*

Mr attention was first directed to this subject by a communication from Government, in which $I$ am requested to endeavour to ascertain "whether the common Cassia Bark of the markets of the world is a thicker and coarser portion of the bark of the genuine cinnamon plant or tree, or whether it is the bark of a plant not analogous to the cinnamon plant or tree."

Before it was possible to return a satisfactory answer to this question, it seemed incumbent on me to ascertain what plant Linnæus meant to designate under the name of Laurus Cassia, and whether it was probable the plant so called could supply all the bark passing under that name in the markets of the world. This primary, but most difficult inquiry was rendered indispensable by the, generally supposed, ridiculous assertion of Mr. Marshall, that the leaves, and the bark of the trunk and branches of the Laurus Cassia of Linnæus, so far from being

- From the Madras Journal of Literature and Science, 1839. No. 22. 
aromatic and spicy like cinnamon, are bitter and have in a slight degree the taste and odour of myrrh. This assertion, wide as it may appear of the truth, is yet founded in fact, and what may appear still more extraordinary, has led to a discovery, which, without such aid as he has given, would not probably have soon been made by a professed botanist, a title to which I believe Mr. Marshall does not aspire. He appears to have been led to the discovery, that the Laurus Cassia of Linnæus did not produce aromatic bark, simply through the native name, and wonders how it could have received from him the name of Cassia, and had qualities attributed to its bark which it does not in the slightest degree possess. I think I can now answer the question, and explain the mystery which has so long hung over this species, and been hitherto rendered only more obscure by each attempt to bring it to light.

It is well known to modern botanists, that many of their earlier predecessors were but indifferent describers of plants, and often very loose in their quotations of figures as synonyms, a $\sin$ of which Linnæus was often about as guilty as any of his cotemporaries. He seemed to have had an idea, that their figures were generally at best but approximations to the truth, and that if a figure exhibited even a remote similarity to a plant before him, especially if from the same country, he might with safety quote it as a synonym. Bearing this in mind, we can easily account for a number of errors to which his incorrect synonyms have given rise. The present instance affords an excellent example of what $I$ have here stated, and one which, but for the discovery of Mr. Marshall, might have long remained undetected.

In Herman's herbarium of Ceylon plants, he (Linnæus) found one bearing the native names of "Dawalkurundu, Nikadawala," under which it is referred to, or described in Herman's 'Musæum Zeylanicum.' This he considered a species of Laurus, apparently from habit alone, and in his usual brief precise style, calls it, "Laurus foliis lanceolatis trinerviis, nervis supra basin unitis ;" having previously called the true cinnamon, "Laurus foliis ovato-oblongis trinerviis basi nervos unientibus." The difference between the two, as indicated by the names, seems very slight, merely depending on the one 
having lanceolate leaves with the nerves united above the base; while in the other the leaves are said to be ovate-oblong with the nerves distinct to the base-differences small indeed, and such as could never be found of much avail in distinguishing the one plant from the other, since they are both constantly met with in different leaves on the same tree. Such being the case, it is not much to be wondered at that botanists should have been surprised by the boldness of Mr. Marshall's announcement, that two trees, believed to be of the same genus, and so nearly alike in their external forms, should yet differ so very widely in their properties. But so it is, and nothing can be more certain than that the fact is as he states it.

In proceeding to trace the history of the two species, aided by the light Mr. Marshall has thrown on them, our difficulties vanish like mist before the noon-day sun, though Mr. Marshall himself has found it "difficult to conceive how the Dawalkurundu obtained the appellation of Laurus Cassia from Linnæus." It was because Linnæus's specimen of Dawalkurundu was neither in flower nor in fruit. Had it been so, he was too acute an observer ever to have confounded it with the plants with which he has associated it in his synonyms. This explanation, it may be answered, is mere assumption on my. part-it certainly is so, but supported by so strong circumstantial evidence, as not to leave a doubt of its correctness. Linnæus has in his ' Flora Zeylanica' given a short description of each of these species : his description of the cinnamon is principally confined to the flower, and is most precise. In his description of the other, the flower is not once alluded to. Here he declares, that he knows not by what mark to distinguish it from the 'camphorifera Japonensium,' which in its foliage it greatly resembles, but nothing can be more distinct than its inflorescence; that of the camphor tree being a panicle, having a stalk as long as the leaves ; while in Dawalkurundu it may be described as a subsessile capitulum, that is, 5 or 6 sessile flowers congested on the apex of a very short peduncle, and surrounded by an involucrum of 4 or 5 leaves; several of which capitula usually form verticels round the naked parts of the branches where the leaves have fallen. He 
begins his description of Laurus Cassia* by stating that he at first considcred it a variety of the antecedent (cinnamon); but now that he knows not by what mark to distinguish it from 'camphorifera Japonensium,' for the leaves are thinner than those of cinnamon, the nerves uniting above the base as in camphorifera, and are sprinkled beneath with a greyish dew (subtus rore casio illinita) as in the camphor tree, and are at the same time lanceolate and of a thinner texture than the preceding (cinnamon). The whole of his description in short agrees most exactly with Mr. Marshall's description of the Cingalese Dawalkurundu, and leaves not a doubt that both had the same plant in view, and consequently that Mr. Marshall is so far correct in saying that the bark of the Laurus Cassia of Linnæus possessed none of the qualities attributed to it. So far all is clear; but now the chapter of errors begins.

Had Linnæus been permitted to exercise his own unbiassed judgement in this case, it is not improbable he would have avoided the error of assigning to a plant which, with all his acuteness, he knew not how to distinguish from the camphor tree, the credit of producing Cassia, or at all events would not have done so without some expression of doubt, so as still to leave the question an open one. But, upon consulting other authorities, he found in Burman's 'Thesaurus Zeylanicus' the figure of a species of Cinnamomum or Laurus as he called the genus, to which Burman had given the name of Cinnamomum perpetuo florens, \&c. and assigned the native name of Dawalkurundu, not as it appears from the specimen itself having been so named, but because being different from the true cinnamon of which he had seen specimens and figures, he thought it an inferior, wild or jungle sort, which must of necessity be the plant that Herman had described in his 'Musæum Zeylanicum,' though the inflorescence differed much from the description, (a very essential point, which Burman remarked and endeavours to explain away, and therefore gave it the

- "Hanc speciem olim pro antecedentis varietate habui, nunc vero, qua nota hanc a camphorifera Japonensium distinguam, non novi; Folia enim Cinnamomo tenuiora, nervis ante basin coeuntibus ut in camphorifera; subtus rore cæsio illinita, ut Camphora, et simul lanceolata ac tenuiori substantia quam præcedentis."-Linn. Flor, Zeylanica, p. 62. 
same Cingalese name. Linnæus's specimen not being in flower, and the resemblance between the specimen and figure being in other respects considerable, he had not the means of detecting the discrepancy, and unsuspectingly adopted Burman's figure and name as a synonym to his plant. In Rheede's 'Hortus Malabaricus,' ( 1 tab. 57) he found the figure of another cinnamon, even more closely resembling his plant in its general aspect than Burman's figure: this he also associated as a synonym; and Rheede's plant being lauded on account of the aromatic properties of its bark and leaves, which resemble the true cinnamon, though it is not the genuine cinnamon tree, he scems to have considered himself quite safe in associating this also, and called the three species, this tria juncto in uno plant, Laurus Cassia, and assigned it as the source of the officinal "Cassia Lignea cortex."

After this exposition of the origin of the species Laurus Cassia, it can scarcely be a matter of surprise that no two botanists have ever agreed as to the plant which ought to bear the name; nor, that not one of them should ever have surmised what plant Linnæus had constituted the type of his species. It is not my intention on the present occasion to extend these remarks, by tracing the various conjectures that have been promulgated on the subject; suffice it to say that no one, so far as I am aware, has taken a similar view as that now explained. It only further remains for me to give some account of the three species thus erroneously associated.

The first mentioned, Dawalkurundu, Linnæus's own plant and the type of the species, is, I believe, the Laurus involucrata of Vahl, and of Lamarck in the 'Encyclopédie Méthodique,' and has in Professor Nees's Monograph of the Indian Laurince (Wall. Plant. As. rariores), received the name of Tetradenia Zeylanica, but is the Litsea Zeylanica of a former work of his, a name which I presume must be restored, owing to the other being preoccupied. The slight difference of structure does not seem to render a new genus necessary.

The second and third have both been referred, by the same eminent botanist, to his variety of the true cinnamon, the Cinnamomum Zeylanicum, a decision to which I cannot subscribe, as $I$ cannot perceive that either of these figures are referable 
to any form of that species, and they besides differ specifically from each other.

The Cinnamomum perpetuo florens appears to me a perfectly distinct species, very nearly allied to, if not actually identical with, Nees's own species C. sulphuratum, of which I have now got specimens from Ceylon. This I infer from the appearance of the plant as represented in the figure, for if any dependence is to be placed on the description, it is impossible to admit it into the genus. On this however, I do not feel disposed to place much reliance, as it was not the practice a century ago, when the description was written, to examine the structure of flowers with the same care that is now bestowed. Should it be objected, that the species I quote as the C.perpetuo florens is clothed with yellowish pubescence, which is not mentioned by Burman, then I have another from the same country (Ceylon) perfectly glabrous, agreeing in the form of its leaves, but differing in having more numerous and smaller flowers, which may be substituted, and that I do not think, more than the other, a variety of the genuine cinnamon tree.

The Malabar plant Carua (Hort. Mal. 1. tab. 57), on the other hand, I consider a very passable figure of a plant, in my herbarium named, by Nees himself, Cinnamomum iners; but, whether or not I am right in the species to which $I$ have referred it, I can have no hesitation in giving it as my opinion that it is not referable to any form of the C. Zeylanicum; neither can I agree with him in thinking the plant figured under the name of Laurus Cassia in the 'Botanical Magazine,' No. 1636, is referable to the Ceylon species, but is I think very like the Malabar one, the only species of the genus to which the name Cassia should be applied, if that name is still to be retained in botanical nomenclature, as being the only one of the three associated species known to produce that drug. To another plate of the 'Botanical Magazine' (Laurus Cinnamomum, No. 2028) I also refer here, and feel greatly at a loss to account for its introduction into that work under a different name from the preceding. The plant which Nees formerly considered the Laurus Cassia, but now calls Cinnamomum aromaticum, from China, is a very nearly allied species, but is distinct, and furnishes much of the bark sold in the Euro- 
pean markets under the name of Cassia, though it has nothing whatever to do with the Laurus Cassia of Linnæus, which, from the preceding history appears strictly confined to Ceylon and India proper, and that name, not being referable to any one species, ought unquestionably to be expunged from botanical nomenclature, its longer continuance there only tending to create confusion and uncertainty. This brings me to the next question-namely, what plant or plants yield the Cassia bark of commerce?

The foregoing explanation, in the course of which two plants are referred to as yielding Cassia, greatly simplifies the answer to this one. The first of these is the Malabar Carua figured by Rheede, the second Nees's Cinnamomum aromaticum. The list, however, of Cassia-producing plants is not limited to these two, but I firmly believe extends to nearly every species of the genus. A set of specimens, submitted for my examination, of the trees furnishing Cassia on the Malabar Coast, presented no fewer than four distinct species ; including among them the genuine cinnamon plant, the bark of the older branches of which, it would appear, is exported from that coast as Cassia. Three or four more species are natives of Ceylon, exclusive of the cinnamon proper, all of which greatly resemble the cinnamon plant, and in the woods might easily be mistaken for it and peeled, though the produce might be inferior. Thus we have from Western India and Ceylon alone, probably not less than six plants producing Cassia; add to these nearly twice as many more species of Cinnamomum, the produce of the more Eastern States of Asia and the Islands of the Eastern Archipelago, all remarkable for their striking family likeness, all I believe endowed with aromatic properties, and probably the greater part if not the whole contributing something towards the general result, and we at once see the impossibility of awarding to any one individual species the credit of being the source whence the Cassia lignea of commerce is derived; and equally the impropriety of applying to any one of them the comprehensive specific appellation of Cassia, since all sorts of cinnamon-like plants, yielding bark of a quality unfit to bear the designation of cinnamon in the market, are passed off as Cassia. 